\title{
T-705 (Favipiravir) suppresses tumor necrosis factor a production in response to influenza virus infection: A beneficial feature of T-705 as an anti-influenza drug
}

\author{
T. TANAKA ${ }^{1,2}$, T. KAMIYAMA ${ }^{1,2}$, T. DAIKOKU ${ }^{1}$, K. TAKAHASHI $^{2}$, N. NOMURA ${ }^{2}$, M. KUROKAWA ${ }^{1,3}$, K. SHIRAKI $^{*}$
}

\begin{abstract}
${ }^{1}$ Department of Virology, University of Toyama, 2630 Sugitani, Toyama 930-0194, Japan; ${ }^{2}$ Research Laboratories, Toyama Chemical Co., Ltd., 2-4-1 Shimookui, Toyama 930-8508, Japan; ${ }^{3}$ Department of Biochemistry, School of Pharmaceutical Sciences, Kyushu University of Health and Welfare, 1714-1 Yoshino, Nobeoka, Miyazaki 882-8508, Japan
\end{abstract}

\begin{abstract}
Summary. - Influenza virus infection induces the production of various cytokines, which play important roles in the pathogenesis of infection. Among the cytokines induced by influenza, tumor necrosis factor $\alpha$ (TNF- $\alpha$ ) production has been correlated with the severity of lung lesions. We investigated the effects of T-705 (Favipiravir, 6-fluoro-3-hydroxy-2-pyrazinecarboxamide) on cytokine production due to influenza virus infection in vitro and in vivo, compared with oseltamivir or GS 4071, an active form of oseltamivir. TNF-a production in mouse macrophage-derived P388D1 cells infected with the influenza virus was lower following treatment with T-705 at concentrations of 0.3 to $100 \mu \mathrm{g} / \mathrm{ml}$ than treatment with GS 4071 at the same concentrations. The effect of treatment with T-705 on the cytokine production induced by the influenza virus infection was investigated in mouse influenza virus infection model. At 48 h post-infection (p.i.) T-705 significantly suppressed the viral load in the lungs and TNF- $\alpha$ production in the airways of infected mice even when viral loads were high. Furthermore, T-705 suppressed only TNF- $\alpha$ production from the early phase of infection. In this study, T-705 showed the antiviral activity of reducing pulmonary viral load compared with oseltamivir, thereby suppressing the TNF- $\alpha$ production. This feature of T-705 is benefit against severe influenza infection.
\end{abstract}

Keywords: influenza; T-705 (Favipiravir); TNF- $\alpha$; cytokines; viral load

\section{Introduction}

T-705 is a novel pyrazine molecule that shows potent anti-influenza virus activity in vitro and in vivo by inhibiting viral RNA synthesis as a chain terminator (Furuta et al., 2002, 2005, 2009; Takahashi et al., 2003; Sangawa et al., 2013). It inhibits the replication and exhibits therapeutic activity in murine model against highly pathogenic avian influenza (HPAI) virus H5N1 (Kiso et al., 2010) and H7N9 virus (Cao

"Corresponding author: E-mail: kshiraki@med.u-toyama.ac.jp phone: +81-76-434-7255.

Abbreviations: HPAI = highly pathogenic avian influenza; MEM = minimum essential medium; $\mathrm{MOI}=$ multiplicity of infec tion; p.i. $=$ post-infection; TNF- $\alpha=$ tumor necrosis factor $\alpha$ et al., 2013; Watanabe et al., 2013). Thus, T-705 is a promising drug for the treatment of influenza virus infections, including HPAI infection in humans. T-705 and oseltamivir showed similar therapeutic activities against mild influenza infection in mice. However, when mice were infected with a high dose of intranasal influenza virus, T-705 prevented their death, while oseltamivir only delayed it (Takahashi et al., 2003). Thus, T-705 seems to be more effective than oseltamivir in alleviating influenza infection, especially in infection with high viral load.

Cytokines are induced by influenza virus infection and play important roles in the development of influenza symptoms. Among the cytokines, tumor necrosis factor $a$ (TNF- $\alpha$ ) plays a crucial role in pathogenesis in the lungs of influenza-infected mice or humans. The severity of gross and histologic lung lesions correlated positively with peak 
bronchoalveolar TNF- $\alpha$ levels and was ameliorated by antiTNF- $\alpha$ treatment without affecting virus titers in the lungs (Peper and Van Campen, 1995). HPAI has been shown to induce high levels of TNF- $\alpha$ in human and murine primary macrophages and to cause severe pneumonia (Cheung et al., 2002; de Jong et al., 2006; Szretter et al., 2007; Monteerarat et al., 2010).

Here we examined the effect of T-705 on TNF- $\alpha$ production due to influenza virus infection in macrophage-like P388D1 cells and in the airways of influenza virus-infected mice to evaluate the contribution of T-705 to the alleviation of influenza infection in vitro and in vivo, compared with oseltamivir and the active form.

\section{Materials and Methods}

Cells and viruses. P388D1 cells were purchased from the American Type Culture Collection (Manassas, VA, USA). P388D1 cells were grown and maintained in RPMI-1640 medium supplemented with $5 \%$ and $2 \%$ heat-inactivated fetal bovine serum (FBS), respectively. Madin-Darby canine kidney (MDCK) cells were grown and maintained in Eagle's minimum essential medium (MEM) supplemented with 10\% FBS. The influenza A/PR/8/34 (H1N1) virus was propagated in MDCK cells and used for cytokine induction in P388D1 cells. The mouse-adapted influenza virus was propagated in the lungs of mice by intranasal infection (Kurokawa
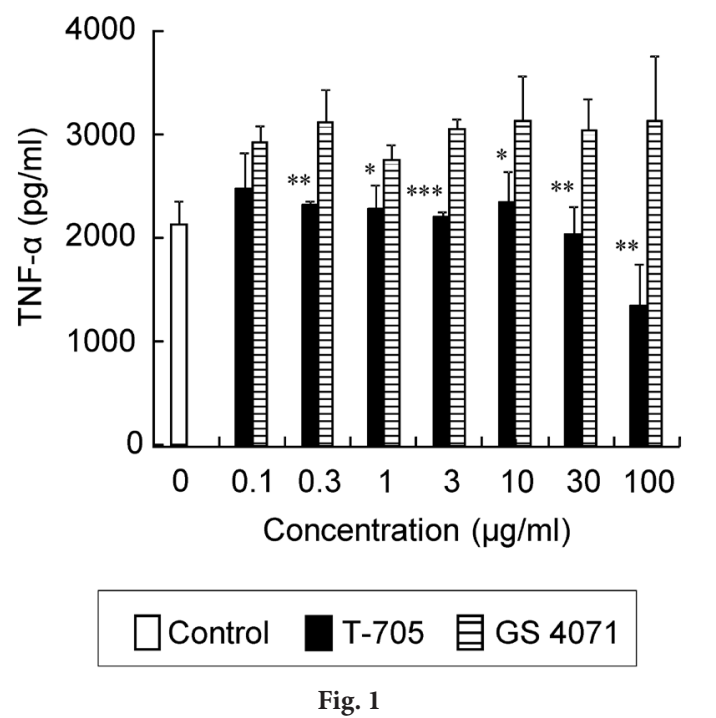

Effect of T-705 on TNF- $\alpha$ production due to influenza A/PR/8/34 (H1N1) virus infection in P388D1 cells

Comparison of TNF- $\alpha$ production in P388D1 cells infected with the influenza virus $(\mathrm{MOI}=2)$ in the absence or presence of T-705 or GS 4071 at various concentrations $24 \mathrm{~h}$ post-infection. TNF- $\alpha$ production of the mock-infected control was $61 \pm 10 \mathrm{pg} / \mathrm{ml}$. Data are expressed as the means \pm S.D. of four samples. ${ }^{\star} P<0.05,{ }^{* *} P<0.01,{ }^{* *} P<0.001$ : significantly different from GS 4071 treatment by t-test. et al., 1996; 1998; 2010; Furuta et al., 2002; 2005; Takahashi et al., 2003). The lungs of infected mice were removed and homogenized in phosphate-buffered saline. The homogenate was centrifuged at $3,000 \mathrm{rpm}$ for $15 \mathrm{~min}$ and then the supernatant was stored at $-80^{\circ} \mathrm{C}$ until its use for intranasal infection.

Compounds. T-705 was synthesized at Toyama Chemical Co., Ltd. (Toyama, Japan). GS 4071 was obtained by extraction from oseltamivir (commercially available drug), followed by hydrolysis according to a conventional method (Kim et al., 1997). The 50\% inhibition concentrations against the influenza A/PR/8/34 (H1N1) virus by T-705 and GS 4071 are 0.16 and $0.0039 \mu \mathrm{g} / \mathrm{ml}$, respectively (Furuta et al., 2002, 2005). T-705 and oseltamivir were resuspended

(a)

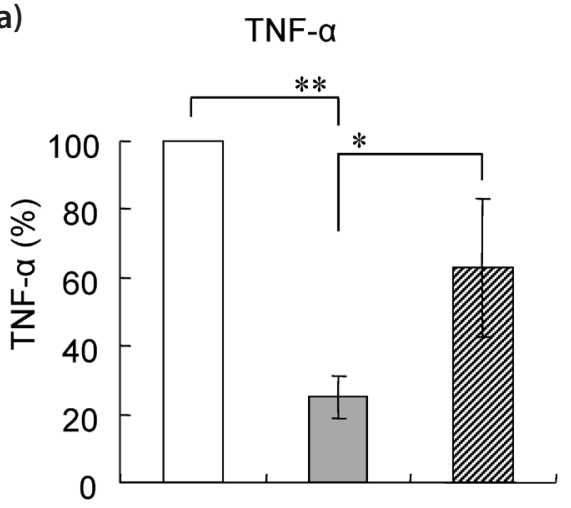

$\mathrm{IL}-1 \alpha$

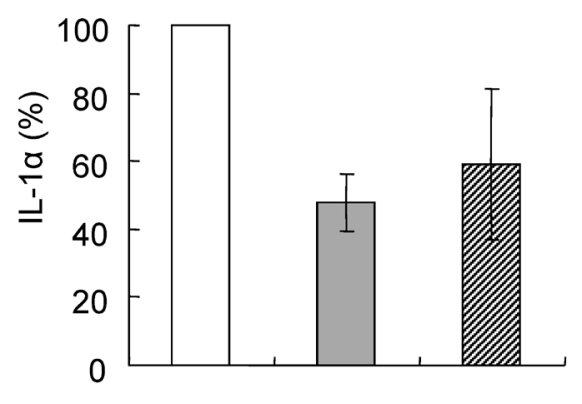

IL-6

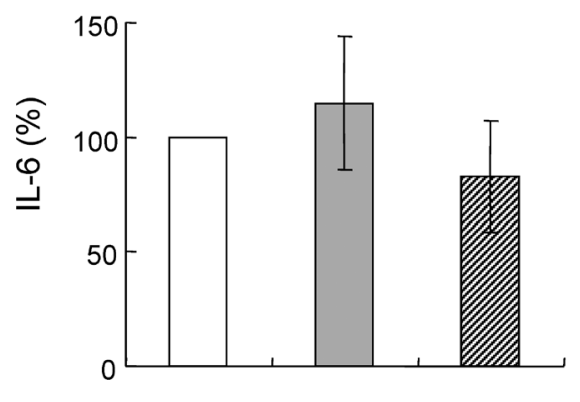

$\square$ Control $\square$ T-705 㚼oseltamivir 
(b)
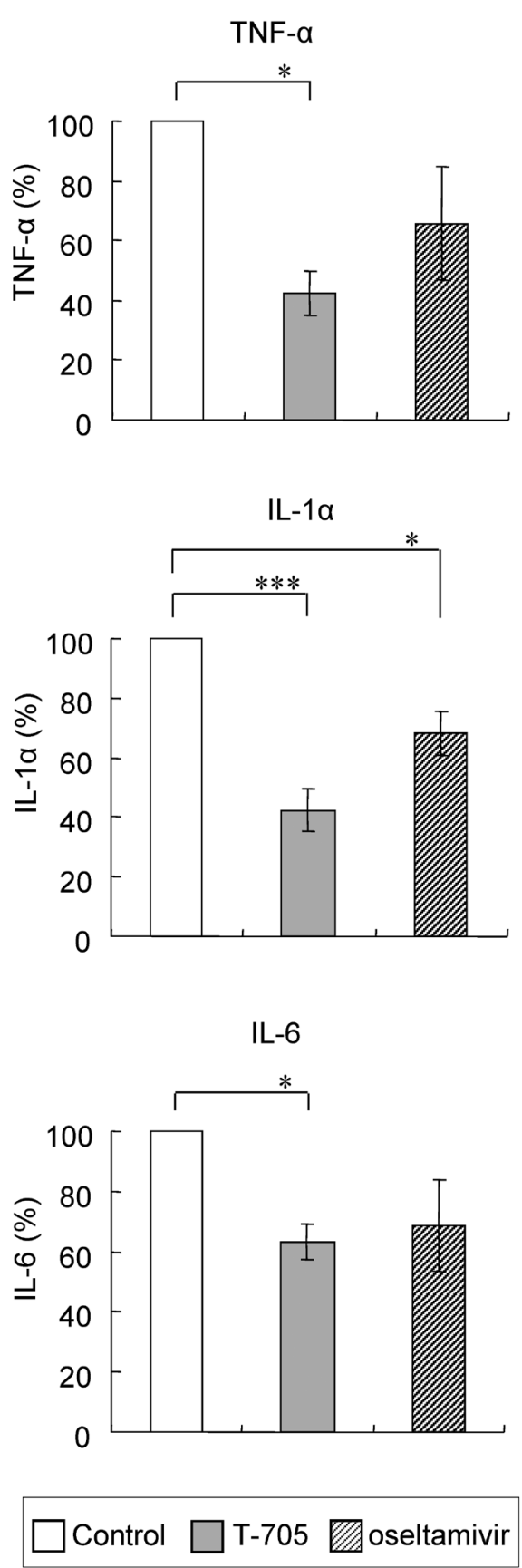

in $0.5 \%$ methylcellulose solution and sterile saline, respectively, and administered orally to mice. As a control, $0.5 \%$ methylcellulose alone was used.

Assay for cytokines secreted from P388D1 cells. The effects of T-705 and GS 4071 on the secretion of pro-inflammatory cytokines (TNF- $\alpha$, IL-la, and IL-6) from P388D1 cells were examined as (c)

$2 \mathrm{~h}$

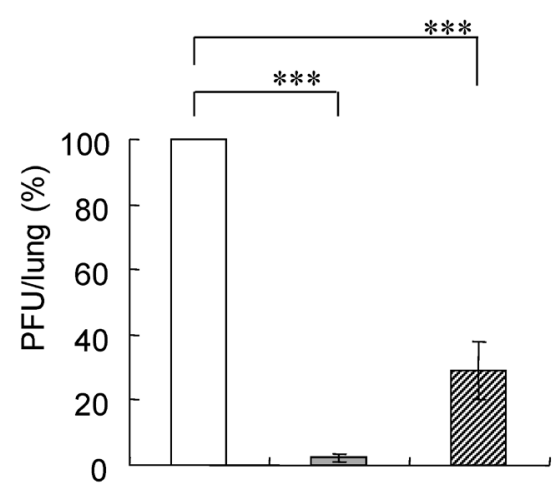

$16 \mathrm{~h}$

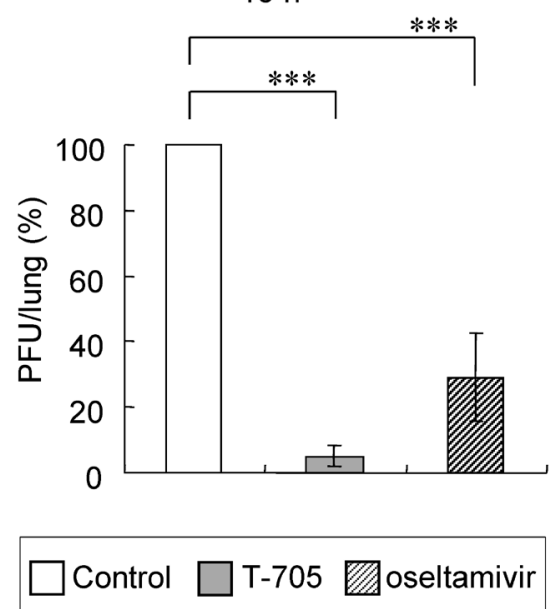

Fig. 2

Effects of T-705 and oseltamivir on cytokine production in BALF and viral loads in the lungs of influenza $\mathrm{A} / \mathrm{PR} / 8 / 34$ virus-infected mice The influenza A/PR/8/34 virus was inoculated nasally and T-705 or oseltamivir was orally administered at doses of 50 or $15 \mathrm{mg} / \mathrm{kg}$, respectively, twice daily beginning $2 \mathrm{~h}$ (a) or $16 \mathrm{~h}$ (b) post-infection. Forty-eight hours post-infection, TNF- $\alpha$, IL- $1 \alpha$ and IL- 6 were assessed in BALF of infected mice treated with T-705, oseltamivir or methylcellulose solution as the control. The viral loads in the lungs were measured by the plaque reduction assay. T-705 or oseltamivir was orally administered beginning $2 \mathrm{~h}$ or $16 \mathrm{~h}$ post-infection (c). The data in bar graph were expressed as the ratio to control, while setting control to $100 \%$. TNF- $\alpha$, IL- $1 \alpha$ and IL-6 levels of control were $628 \pm 135,378 \pm 99,1453 \pm 174 \mathrm{pg} / \mathrm{ml}$, respectively, and viral load of control was $8.28 \pm 0.09 \log \mathrm{PFU} / \mathrm{g}$ lung. Five or six mice were used for each experimental assay to determine the mean \pm S.D. ${ }^{*} P<0.05$, ${ }^{*} P<0.01$, ${ }^{* *} P<0.001$ : significantly different from each group by Tukey's test.

described previously (Kurokawa et al., 2003, 2010). P388D1 cells were seeded at $5 \times 10^{5}$ cells/well in 24 -well tissue culture plates and grown at $37^{\circ} \mathrm{C}$ overnight. Cells were mock-infected and infected with the influenza A/PR/8/34 (H1N1) virus at a multiplicity of infection (MOI) of 2 plaque-forming units (PFU)/cell and cultured for $1 \mathrm{~h}$ without drugs. Infected cells were then treated with $\mathrm{T}-705$ or 
TNF- $\alpha$

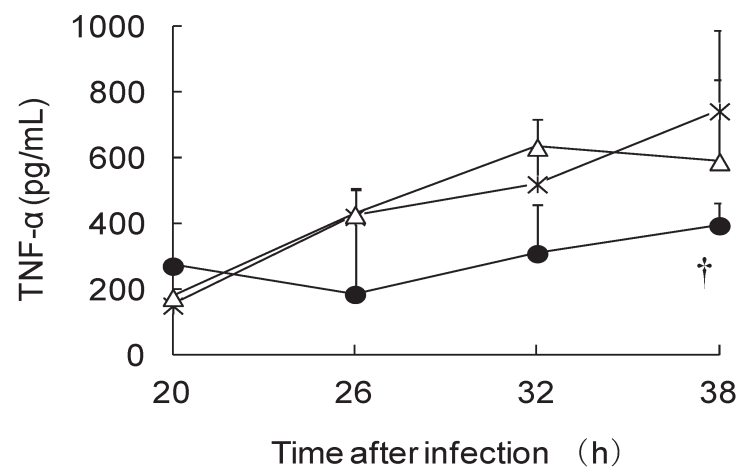

$\mathrm{IL}-1 \alpha$

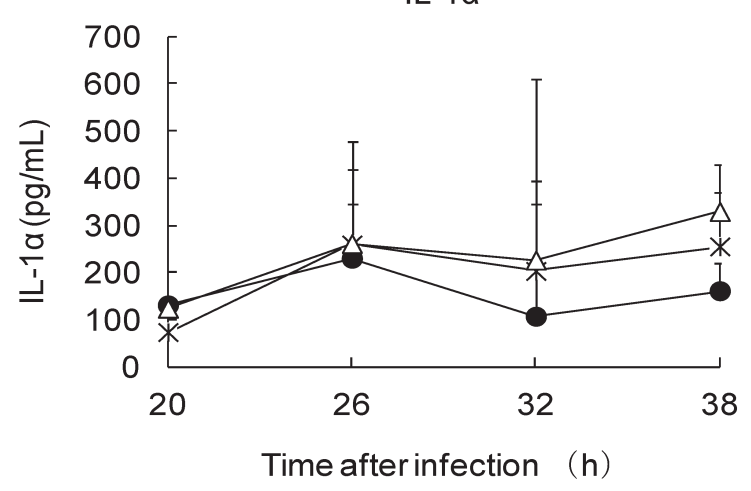

IL-6

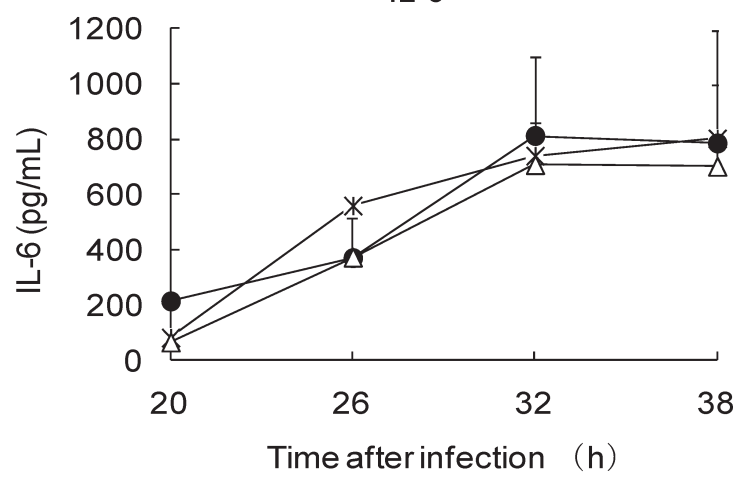

IL-12

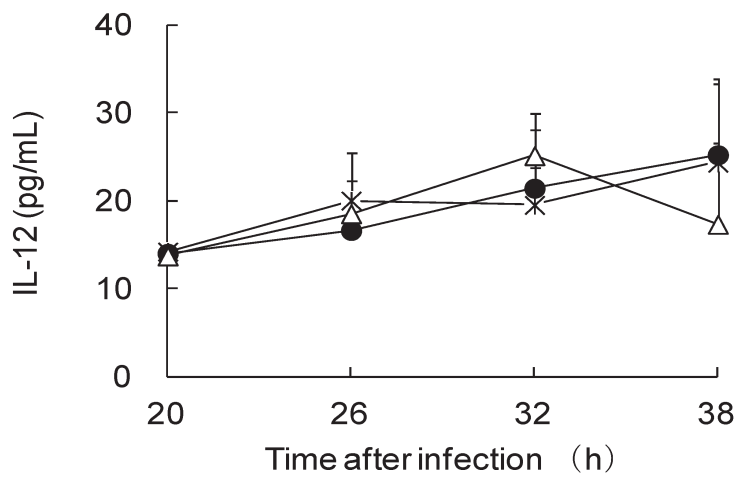

MIP-2

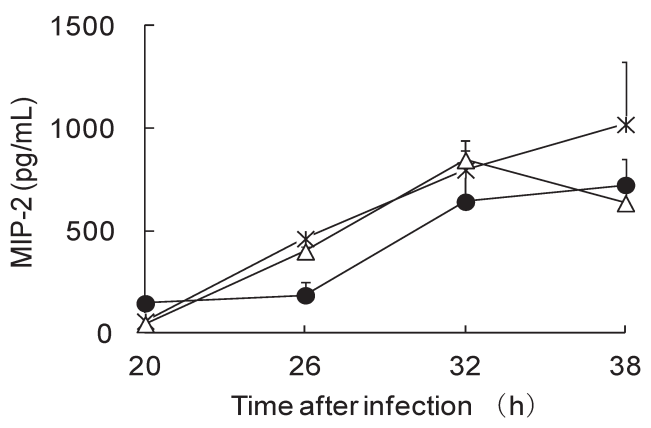

IFN-Y

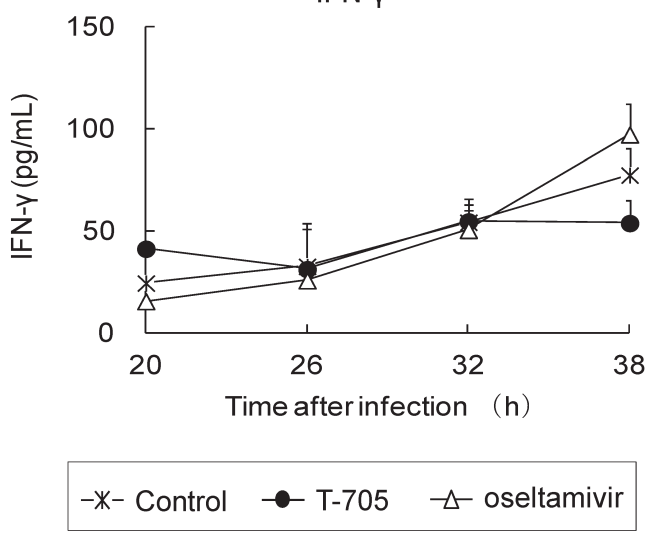

Fig. 3

Time course study of effects of T-705 and oseltamivir on cytokine production in BALF of influenza $A / P R / 8 / 34$ virus-infected mice The influenza A/PR/8/34 virus was inoculated nasally and T-705 or oseltamivir was orally administered at a dose of $50 \mathrm{mg} / \mathrm{kg}$ four times daily ( $6 \mathrm{~h}$ intervals) beginning $16 \mathrm{~h}$ post-infection. TNF- $\alpha$, IL-1 $\alpha$, IL-6, MIP-2, IL-12 and IFN- $\gamma$ were assessed in BALF of infected mice treated with T-705, oseltamivir or methylcellulose solution as the control 20, 26, 32 and $38 \mathrm{~h}$ post-infection. Three to five mice were used for each experimental assay to determine the mean \pm S.D. $\uparrow P<0.05$ : vs. oseltamivir by one-way ANOVA.

GS 4071 at $0.1,0.3,1,3,10,30$, or $100 \mu \mathrm{g} / \mathrm{ml}$. The culture medium was collected and centrifuged at $24 \mathrm{~h}$ p.i.

Cytotoxicity assay. The cytotoxicity of T-705 and GS 4071 was evaluated by an assay using 2,3-bis(2-methoxy-4-nitro5-sulfopheny1)-5-[(phenylamino)carbony1]-2H-tetrazolium hydroxide (XTT) as described previously (Scudiero et al., 1988; Furuta et al., 2002).

Mice. Female DBA/2 Cr mice (6-7-week-old, 17-22 g, Japan SLC Inc., Shizuoka, Japan) were housed five per cage in a temperaturecontrolled room under a $12 \mathrm{~h}$ light/12 h dark diurnal cycle (lights on at 7.00 a.m.) with food and water provided ad libitum. The temperature in the room was kept at $23 \pm 2^{\circ} \mathrm{C}$. Mice were acclimated for at least 4 days before starting experimental procedures. The animal experimentation guidelines of the University of Toyama 
or the Laboratory Animal Use Management Regulation at Toyama Chemical Co., Ltd. were followed in the animal studies.

Murine influenza virus infection model. Mice were intranasally infected with the mouse-adapted influenza virus A/PR/8/34 (H1N1) at 1,000 PFU (Kurokawa et al., 1996, 1998, 2010; Furuta et al., 2002, 2005; Takahashi et al., 2003) and the effects of T-705 and oseltamivir administration on cytokine levels in the bronchoalveolar lavage fluid (BALF) and viral loads in the lungs of infected mice at $48 \mathrm{~h}$ p.i. were examined. T-705 or oseltamivir were orally administered at doses of 15 or $50 \mathrm{mg} / \mathrm{kg}$, twice daily, beginning 2 and $16 \mathrm{~h}$ p.i. In time course study, each drug was administered at a dose of $50 \mathrm{mg} / \mathrm{kg}$ four times daily ( $6 \mathrm{~h}$ intervals) beginning $16 \mathrm{~h}$ p.i. BALF was collected via a tracheal cannula to examine cytokine levels. Three to six mice were used for each experimental assay.

ELISA. Cytokine levels in the culture supernatants of P388D1 cells or in BALF were measured with ELISA kits (BioSource, Camarillo, CA, USA or R\&D Systems, Minneapolis, MN, USA) according to the manufacturer's instructions.

Lung virus titration. Virus titers in the lungs of mice were determined in 12-well plates of MDCK cells with serial dilutions of lung homogenates in MEM containing 0.001\% DEAE-dextran, $2 \mu \mathrm{g} / \mathrm{ml} \mathrm{TPCK}$-treated trypsin, and $0.5 \%$ agarose for 2 days at $35^{\circ} \mathrm{C}$. Cells were stained with $0.005 \%$ amido black solution and plaque numbers were counted.

Statistical analyses. Statistical analyses of cytokine levels in P388D1 cells, in the BALF of mice and in time course study were performed by t-test, Tukey's test and one-way ANOVA, respectively. A $P$-value less than 0.05 was defined as significant. SAS release 9.2 (SAS Institute Japan Ltd., Tokyo, Japan), Stat Preclinica 1.2 (Takumi Information Technology Inc., Tokyo, Japan) and Statcel 3 (OMS Publishing, Saitama, Japan) were used as the analytical software.

\section{Results}

Effects of T-705 and GS 4071 on cytokine secretion by infected P388D1 cells

We investigated the induction of pro-inflammatory cytokines (TNF- $\alpha$, IL-l $\alpha$ and IL-6) in macrophage-like P388D1 cells infected with the influenza virus and observed that TNF- $\alpha$ was induced at MOI of 1 or more at $24 \mathrm{~h}$ p.i., while no induction of IL-la and IL-6 was observed until $24 \mathrm{~h}$ p.i. (data not shown). As shown in Fig. 1, significant suppression of TNF- $\alpha$ production by T-705 was observed at 0.3 to $100 \mu \mathrm{g} /$ $\mathrm{ml}$, compared with GS 4071 at the same concentrations and the suppression of TNF- $\alpha$ production by T-705 became stronger at more than $30 \mu \mathrm{g} / \mathrm{ml}$. T-705 and GS 4071 showed no cytotoxicity against P388D1 cells at the concentration of $100 \mu \mathrm{g} / \mathrm{ml}$ (data not shown). T-705 suppressed TNF- $\alpha$ production from P388D1 cells more than GS 4071.
Effects of T-705 and oseltamivir on cytokine production in BALF and viral loads in the lungs of infected mice at $48 \mathrm{~h}$ p.i.

We measured cytokine levels in BALF of influenza virusinfected mice treated with each drug to investigate the effects of T-705 and oseltamivir on cytokine production as shown in Fig. 2. T-705 and oseltamivir with the treatment from $2 \mathrm{~h}$ p.i. inhibited TNF- $\alpha$ and IL-la production at $48 \mathrm{~h}$ p.i. and especially, TNF- $a$ production was significantly inhibited by T-705 more than by oseltamivir (Fig. 2a). IL-6 production was not influenced by T-705 or oseltamivir. When the treatments with T-705 and oseltamivir were started at $16 \mathrm{~h}$ p.i., TNF- $\alpha$, IL- $1 \alpha$, and IL- 6 were significantly suppressed by T-705 and oseltamivir (Fig. 2b). The viral loads in the lungs of mice with treatment started at $16 \mathrm{~h}$ p.i. were about $10^{4}$ times higher than those in the lungs of mice with treatment started at $2 \mathrm{~h}$ p.i. $(6.65 \pm 0.06$ and $2.57 \pm 0.24 \mathrm{log} \mathrm{PFU} / \mathrm{g}$ lung, respectively). T-705 had tendency to inhibit TNF- $a$ production more than oseltamivir at $16 \mathrm{~h}$ p.i., but not significantly $(P=0.12)$. T-705 significantly suppressed the viral load in the lung of mice treated from $2 \mathrm{~h}$ and from $16 \mathrm{~h}$ p.i. compared with oseltamivir and control (Fig. 2c). Cytokine levels were not necessarily correlated with viral loads in the lungs, however, TNF- $\alpha$ production was suppressed in proportion to the lung viral loads.

\section{Effects of T-705 and oseltamivir on cytokine production in time course study in the BALF of infected mice}

T-705 and oseltamivir inhibited pro-inflammatory cytokines including TNF- $\alpha$ at 48 h p.i. (Fig. 2b). Secondly, we investigated the inhibitory effect of these compounds on pro-inflammatory cytokines production from $20 \mathrm{~h}$ p.i., at earlier phase of infection. When we measured cytokine levels in the BALF of influenza virus-infected mice treated with each drug from 16 h p.i., T-705 significantly suppressed TNF- $\alpha$ production among measured cytokines from 20 h p.i., compared with oseltamivir as shown in Fig. 3, whereas other cytokines tested, IL-1a, IL-6, MIP-2, IL-12 and IFN- $\gamma$, showed no difference between the two treatments.

\section{Discussion}

In this study, we investigated the effect of T-705 on cytokine production in influenza virus infection in vitro and in vivo. Cytokines, particularly TNF- $\alpha$, play important roles in the pathogenesis of influenza, and TNF- $\alpha$ has been correlated with the severity of infection (Peper and Van Campen, 1995; Kurokawa et al., 1996, 2010; Hussell et al., 2001; Cheung et al., 2002; Peiris et al., 2004; Chan et al., 2005; Szretter et al., 
2007). The relationship between nasopharyngeal cytokine responses and symptom formation has been evaluated in clinical trials assessing the effects of anti-influenza drugs (Hayden et al., 1998, 1999; Fritz et al., 1999; Watanabe et al., 2013). The inhibition of viral replication was associated with the abrogation of cytokine production and reduction in symptom magnitude in volunteers treated with zanamivir, oseltamivir or rimantadine. The modes of cytokine production in the early phase of influenza virus infection following treatment with anti-influenza drugs may reflect their efficacy against influenza symptoms. In this study, we observed that the production of TNF- $\alpha$ in both cultured cells and influenza virus-infected mice was lower after T-705 treatment than after treatment with GS 4071 and oseltamivir. In particular, TNF- $\alpha$ production was inhibited by T-705 during the early phase of infection when mice were treated from $16 \mathrm{~h}$ p.i. The suppression of TNF- $\alpha$ production by T-705 from the early phase of infection in this study may be associated with the alleviation of influenza infection in addition to its anti-influenza virus activity and these effects may have contributed to its therapeutic efficacy in mouse model of influenza virus infection under the conditions of both a high viral challenge dose and the initiation of therapy delayed to 25 h p.i. (Takahashi et al., 2003).

TNF- $\alpha$ is induced due to recognition of single-strand RNA or double-strand RNA of the influenza virus genome by Toll-like receptor (TLR)-7/8 or TLR-3, respectively, in infected cells (MacEwan, 2002; Takeda and Akira, 2004; Karin and Gallagher, 2009; Yoneyama and Fujita, 2010). The differential effects on TNF- $\alpha$ production by T-705 and oseltamivir may be due to differences in their antiviral action on the influenza virus. Oseltamivir permits viral RNA synthesis and progeny virus production in infected cells, while T-705 inhibits intracellular viral RNA synthesis and viral replication. TNF- $\alpha$ was first induced and declined in P388D1 cells and IL-1 $\alpha$ and IL- 6 followed. Therefore, TNF- $\alpha$ might be the most suitable cytokine for evaluating the effect of both drugs on cytokines. The difference in genomic RNA synthesis may explain the differential induction of TNF-a production through TLR signaling among cytokines. Expression of pro-inflammatory cytokines (like TNF- $\alpha$ ) is induced by transcription factors, such as NF- $\kappa B$, whereas it is reported that activation of NF- $\kappa \mathrm{B}$ is prevented by influenza virus NS1 protein (Wang et al., 2000). Complex factors, such as interferons, cytokines, chemokines or signal transduction are involved in the expression of pro-inflammatory cytokines. In this study, among various pro-inflammatory cytokines only TNF- $\alpha$ had decreased following treatment with T-705; this effect, based on the mode of action of T-705, is of significant value in patients with influenza in alleviating influenza pneumonia because TNF- $\alpha$ is a key factor involved in lung injury that causes pneumonia (Peper and Van Campen, 1995).
In this study, we compared the effect of T-705 and oseltamivir on murine cytokine production and viral loads in influenza A virus infection in vitro and in vivo. It was found that T-705 suppressed the production of TNF- $\alpha$ relative to oseltamivir. The viral loads seemed not to be proportional to the cytokine levels in the lungs, but to some extent to the TNF- $\alpha$ levels, and suppression of TNF- $\alpha$ production seemed to reflect the potent antiviral effect of T-705. T-705 suppressed viral load in the lungs and thereby suppressed TNF- $\alpha$ by reducing intracellular viral RNA and its subsequent reduced TLR signaling for TNF- $\alpha$. The apparent specific suppression of TNF- $a$ production is a beneficial feature of T-705 in the treatment of severe influenza including HPAI infection. This could also explain why influenza-infected animals with delayed treatment showed differences in survival, where the infection has progressed to a state of substantial tissue damage, which is difficult to control through the mechanisms elucidated by oseltamivir.

Acknowledgements. We thank Ms. T. Okuda and Mr. Y. Yoshida for their excellent technical assistance, Dr. S. Minami for helpful discussion, and Ms. Katherine Ono for her editorial assistance. This work was partly supported by Toyama Chemical Co. Ltd.

\section{References}

Cao RY, Xiao JH, Cao B, Li S, Kumaki Y, Zhong W (2014): Inhibition of novel reassortant avian influenza H7N9 virus infection in vitro with three antiviral drugs, oseltamivir, peramivir and favipiravir. Antivir. Chem. Chemother. 23, 237-240. https://doi.org/10.3851/IMP2672

Cheung CY, Poon LL, Lau AS, Luk W, Lau YL, Shortridge KF, Gordon S, Guan Y, Peiris JS (2002): Induction of proinflammatory cytokines in human macrophages by influenza A (H5N1) viruses: a mechanism for the unusual severity of human disease? Lancet 360, 1831-1837. https://doi. org/10.1016/S0140-6736(02)11772-7

de Jong MD, Simmons CP, Thanh TT, Hien VM, Smith GJ, Chau TN, Hoang DM, Chau NV, Khanh TH, Dong VC, Qui PT, Cam BV, Ha do Q, Guan Y, Peiris JS, Chinh NT, Hien TT, Farrar $J$ (2006): Fatal outcome of human influenza A (H5N1) is associated with high viral load and hypercytokinemia. Nat. Med. 12, 1203-1207. https://doi.org/10.1038/nm1477

Chan MC, Cheung CY, Chui WH, Tsao SW, Nicholls JM, Chan YO, Chan RW, Long HT, Poon LL, Guan Y, Peiris JS (2005): Proinflammatory cytokine responses induced by influenza A (H5N1) viruses in primary human alveolar and bronchial epithelial cells. Respir. Res. 6, 135. https:// doi.org/10.1186/1465-9921-6-135

Fritz RS, Hayden FG, Calfee DP, Cass LM, Peng AW, Alvord WG, Strober W, Straus SE (1999): Nasal cytokine and chemokine responses in experimental influenza A virus infection: results of a placebo-controlled trial of intravenous zanamivir treatment. J. Infect. Dis. 180, 586-593. https:// doi.org/10.1086/314938 
Furuta Y, Takahashi K, Fukuda Y, Kuno M, Kamiyama T, Kozaki K, Nomura N, Egawa H, Minami S, Watanabe Y, Narita $\mathrm{H}$, Shiraki K (2002): In vitro and in vivo activities of anti-influenza virus compound T-705. Antimicrob. Agents Chemother. 46, 977-981. https://doi.org/10.1128/ AAC.46.4.977-981.2002

Furuta Y, Takahashi K, Kuno-Maekawa M, Sangawa H, Uehara S, Kozaki K, Nomura N, Egawa H, Shiraki K (2005): Mechanism of action of T-705 against influenza virus. Antimicrob Agents Chemother. 49, 981-986. https://doi. org/10.1128/AAC.49.3.981-986.2005

Furuta Y, Takahashi K, Shiraki K, Sakamoto K, Smee DF, Barnard DL, Gowen BB, Julander JG, Morrey JD (2009): T-705 (favipiravir) and related compounds: Novel broad-spectrum inhibitors of RNA viral infections. Antiviral. Res. 82, 95-102. https://doi.org/10.1016/j.antiviral.2009.02.198

Hayden FG, Fritz R, Lobo MC, Alvord W, Strober W, Straus SE (1998): Local and systemic cytokine responses during experimental human influenza A virus infection. Relation to symptom formation and host defense. J. Clin. Invest. 101, 643-649. https://doi.org/10.1172/JCI1355

Hayden FG, Treanor JJ, Fritz RS, Lobo M, Betts RF, Miller M, Kinnersley N, Mills RG, Ward P, Straus SE (1999): Use of the oral neuraminidase inhibitor oseltamivir in experimental human influenza: randomized controlled trials for prevention and treatment. JAMA 282, 1240-1246. https:// doi.org/10.1001/jama.282.13.1240

Hussell T, Pennycook A, Openshaw PJ (2001): Inhibition of tumor necrosis factor reduces the severity of virusspecific lung immunopathology. Eur. J. Immunol. 31, 2566-2573. https://doi.org/10.1002/1521-4141(200109)31:9<2566::AID-IMMU2566>3.0.CO;2-L

Karin M, Gallagher E (2009): TNFR signaling: ubiquitin-conjugated TRAFfic signals control stop-and-go for MAPK signaling complexes. Immunol. Rev. 228, 225-240. https://doi. org/10.1111/j.1600-065X.2008.00755.X

Kim CU, Lew W, Williams MA, Liu H, Zhang L, Swaminathan S, Bischofberger N, Chen MS, Mendel DB, Tai CY, Laver WG, Stevens RC (1997): Influenza neuraminidase inhibitors possessing a novel hydrophobic interaction in the enzyme active site: design, synthesis, and structural analysis of carbocyclic sialic acid analogues with potent anti-influenza activity. J. Am. Chem. Soc. 119, 681-690. https://doi.org/10.1021/ja963036t

Kiso M, Takahashi K, Sakai-Tagawa Y, Shinya K, Sakabe S, Le QM, Ozawa M, Furuta Y, Kawaoka Y (2010): T-705 (favipiravir) activity against lethal $\mathrm{H} 5 \mathrm{~N} 1$ influenza A viruses. Proc. Natl. Acad. Sci. USA 107, 882-887. https://doi. org/10.1073/pnas.0909603107

Kurokawa M, Imakita M, Kumeda CA, Shiraki K (1996): Cascade of fever production in mice infected with influenza virus. J. Med. Virol. 50, 152-158. https://doi. org/10.1002/(SICI) 1096-9071(199610)50:2<152::AIDJMV8>3.0.CO;2-9

Kurokawa M, Kumeda CA, Yamamura J, Kamiyama T, Shiraki K (1998): Antipyretic activity of cinnamyl derivatives and related compounds in influenza virus-infected mice.
Eur. J. Pharmacol. 348, 45-51. https://doi.org/10.1016/ S0014-2999(98)00121-6

Kurokawa M, Brown J, Kagawa Y, Shiraki K (2003): Cytokine-regulatory activity and therapeutic efficacy of cinnamyl derivatives in endotoxin shock. Eur. J. Pharmacol. 474, 283-293. https://doi.org/10.1016/S0014-2999(03)02036-3

Kurokawa M, Watanabe W, Shimizu T, Sawamura R, Shiraki K (2010): Modulation of cytokine production by 7-hydroxycoumarin in vitro and its efficacy against influenza infection in mice. Antiviral. Res. 85, 373-380. https://doi. org/10.1016/j.antiviral.2009.11.001

MacEwan DJ (2002): TNF receptor subtype signalling: differences and cellular consequences. Cell Signal. 14, 477-492. https://doi.org/10.1016/S0898-6568(01)00262-5

Monteerarat Y, Sakabe S, Ngamurulert S, Srichatraphimuk S, Jiamtom W, Chaichuen K, Thitithanyanont A, Permpikul P, Songserm T, Puthavathana P, Nidom CA, Mai le Q, Iwatsuki-Horimoto K, Kawaoka Y, Auewarakul P (2010): Induction of TNF-alpha in human macrophages by avian and human influenza viruses. Arch. Virol. 155, 1273-1279. https://doi.org/10.1007/s00705-010-0716-y

Peiris JS, Yu WC, Leung CW, Cheung CY, Ng WF, Nicholls JM, Ng TK, Chan KH, Lai ST, Lim WL, Yuen KY, Guan Y (2004): Re-emergence of fatal human influenza A subtype H5N1 disease. Lancet 363, 617-619. https://doi.org/10.1016/ $\underline{\text { S0140-6736(04)15595-5 }}$

Peper RL, Van Campen H (1995): Tumor necrosis factor as a mediator of inflammation in influenza A viral pneumonia. Microb. Pathog. 19, 175-183. https://doi.org/10.1006/ mpat.1995.0056

Sangawa H, Komeno T, Nishikawa H, Yoshida A, Takahashi K, Nomura N, Furuta Y (2013): Mechanism of action of T-705 ribosyl triphosphate against influenza virus RNA polymerase. Antimicrob. Agents Chemother. 57, 52025208. https://doi.org/10.1128/AAC.00649-13

Scudiero DA, Shoemaker RH, Paull KD, Monks A, Tierney S, Nofziger TH, Currens MJ, Seniff D, Boyd MR (1988): Evaluation of a soluble tetrazolium/formazan assay for cell growth and drug sensitivity in culture using human and other tumor cell lines. Cancer Res. 48, 4827-4833.

Szretter KJ, Gangappa S, Lu X, Smith C, Shieh WJ, Zaki SR, Sambhara S, Tumpey TM, Katz JM (2007): Role of host cytokine responses in the pathogenesis of avian $\mathrm{H} 5 \mathrm{~N} 1$ influenza viruses in mice. J. Virol. 81, 2736-2744. https:// doi.org/10.1128/JVI.02336-06

Takahashi K, Furuta Y, Fukuda Y, Kuno M, Kamiyama T, Kozaki K, Nomura N, Egawa H, Minami S, Shiraki K (2003): In vitro and in vivo activities of T-705 and oseltamivir against influenza virus. Antivir Chem Chemother. 14, 235-241. https://doi.org/10.1177/095632020301400502

Takeda K, Akira S (2004): TLR signaling pathways. Semin. Immunol. 16, 3-9. https://doi.org/10.1016/j.smim.2003.10.003

Wang X, Li M, Zheng H, Muster T, Palese P, Beg AA, García-Sastre A (2000): Influenza A virus NS1 protein prevents activation of NF-kappaB and induction of alpha/beta interferon. J. Virol. 74, 11566-11573. https://doi.org/10.1128/ JVI.74.24.11566-11573.2000 
Watanabe T, Kiso M, Fukuyama S, Nakajima N, Imai M, Yamada S, Murakami S, Yamayoshi S, Iwatsuki-Horimoto K, Sakoda Y, Takashita E, McBride R, Noda T, Hatta M, Imai H, Zhao D, Kishida N, Shirakura M, de Vries RP, Shichinohe S, Okamatsu M, Tamura T, Tomita Y, Fujimoto N, Goto K, Katsura H, Kawakami E, Ishikawa I, Watanabe S, Ito M, Sakai-Tagawa Y, Sugita Y, Uraki R, Yamaji R, Eisfeld AJ, Zhong G, Fan S, Ping J, Maher EA, Hanson
A, Uchida Y, Saito T, Ozawa M, Neumann G, Kida H, Odagiri T, Paulson JC, Hasegawa H, Tashiro M, Kawaoka Y (2013): Characterization of H7N9 influenza A viruses isolated from humans. Nature 501, 551-555. https://doi. org/10.1038/nature12392

Yoneyama M, Fujita T (2010): Recognition of viral nucleic acids in innate immunity. Rev. Med. Virol. 20, 4-22. https://doi. org/10.1002/rmv.633 